\title{
Planktonic Foraminiferal Biostratigraphy of Shiranish Formation in Dohuk Area/ Northern Iraq
}

\author{
Majid M. Al-Mutwali Mazin A. AL-Doori \\ Department of Geology \\ College of Science \\ University of mosul
}

(Received 28/9/2011, Accepted 13/3/2012)

\begin{abstract}
ABSITRACT
The litho-and biostratigraphy of Shiranish Formation have been investigated within a well-exposed section at the southern limb of Bekhair anticline, Dohuk area, Northern Iraq. The studied section consists mainly of marl, marly limestone, and limestone. The Formation unconformably overlies Bekhme Formation and it is overlain unconformably by the Kolosh Formation. The samples of the section under investigation yielded rich and well diversified planktonic foraminiferal taxa, where 55 planktonic species belonging to 16 genera have been recognized, the detailed foraminiferal investigation permits the recognition of 8 well defined zones. These are from older at the base:

8. Plummerita hantkeninoides Total range Zone (Part).

7. Pseudoguembelina palpebra Partial range Zone.

6. Pseudoguembelina hariaensis Interval Zone.

5.Racemiguembelina fructicosa Interval Zone.

4. Planoglobulina acervulinoides Partial range Zone.

3. Contusotruncana contusa Interval Zone.

2. Gansserina gansseri Interval Zone.

1. Globotruncana aegyptiaca Interval Zone (Part).

The Planktonic zones were correlated with other zonal schems in and outside Iraq. They are considered to be extending from middle Late Campanian to latest Maastrichtian.
\end{abstract}




\section{الطباقية الحياتية للقورامنيفرا الطافية لتكوين شرانش في منطقة دهوك/ شمال العراق}

$$
\text { قسم علوم الأرض كلبة العلوم }
$$$$
\text { ماجد مجدي المتولي }
$$

الملخص

تضمن البحث الحالي دراسة الصخارية والطباقية الحياتية لتكوين شرانش في المقطع السطحي الذي

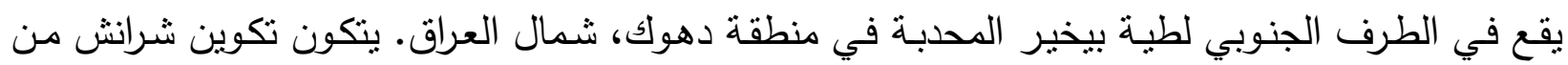
صخور المارل والحجر الجيري المارلي والحجر الجيري ويحده من الأسفل بصورة غير منوافقة طباقيا تكوين بخمة ومن الاعلى تكوين كولوش بشكل غير متوافق طباقيا. تحتوي تتابعات تكوين شرانش على حشود غزيرة

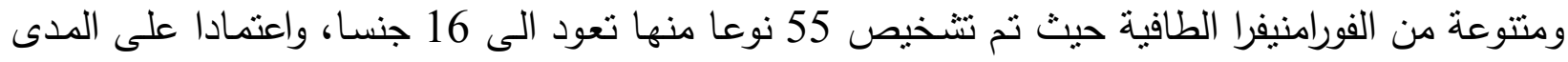
الجيولوجي لهذه الأنواع تم تقسيم التكوين الى ثمانية انطقة حياتية وهي كما يلي من الأقدم في الأسفل:

8. Plummerita hantkeninoides Total range Zone (Part).

7. Pseudoguembelina palpebra Partial range Zone.

6. Pseudoguembelina hariaensis Interval Zone.

5. Racemiguembelina fructicosa Interval Zone.

4. Planoglobulina acervulinoides Partial range Zone.

3. Contusotruncana contusa Interval Zone.

2. Gansserina gansseri Interval Zone.

1. Globotruncana aegyptiaca Interval Zone (Part).

تم مضاهاة هذه الانطقة الحياتية مع الانطقة الحياتية لدراسات داخل العراق وخارجه وحدد على اساس

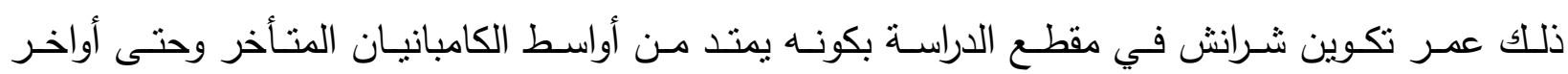
الماسترختيان. 
The studied section is located on southern limb of Bekhair anticline $9 \mathrm{~km}$ northeast of Dohuk city (Fig . 1). The Shiranish Formation belongs to the most widespread units of the Campanian - Maastrichtian transgressive cycle in Iraq and also in the neighbouring countries.The Shiranish Formation was first defined by (Henson 1940 in Bellen et al. 1959) from the highly folded zone of northern Iraq near the village of Shiranish Islam about $17 \mathrm{~km}$ Northeastern of Zakho, It attains a thickness of $227 \mathrm{~m}$. consist of foraminiferal marl, marly limestone and limestone, it was deposited in outer shelf to basinal environments (Jassim and Goff, 2006). The purpose of this paper is to record the planktonic species and establish the biostratigraphic zones and correlate them with their equivalent biozones in and outside Iraq in order to determine the age of the studied section.

\section{Lithostratigraphy and Contact Boundaries:}

Shiranish Formation $57 \mathrm{~m}$. thick composed of alternations of marl, marly limestone and thin beds of limestone (Fig. 2), it can be subdivided into two units, the lower part of this formation consists mainly of marly limestone beds alternate with thin marl beds, while the upper part consists mainly of marl beds alternate with marly limestone beds. Shiranish Formation unconformably overlies the Bekhme Formation (AL-Haidary, 2009) and unconformably overlained by Kolosh Formation. (AL - Wazan, 2007) (Fig.3 and 4).

\section{Materials and Methods:}

Therty seven rock samples were collected at $(2-0.5) \mathrm{m}$. intervals from the studied section. About $30 \mathrm{~g}$. of each sample was weighed, crushted, and boiled for $(10$ - 30) hours, washed over 230 mesh sieve with tap water, dried and size - sorted using a set of sieves $(40,60,80,100,120$ mesh), then ultrasonically agitated for (10 - 30) minuts, all specimens were picked and mounted on microslides for identification under binocular microscope.

\section{Biostratigraphy:}

The investigation of foraminiferal assemblages within the studied section revealed that planktonic species are abundant within marl, whereas they are rare or absent within the marly limestone and the limestone bed. Planktonic foraminifera have been used for biostratigraphic analysis for the studied section, their systematic study enabled the writers to identify fifty-five planktonic species ( Fig. 5). 


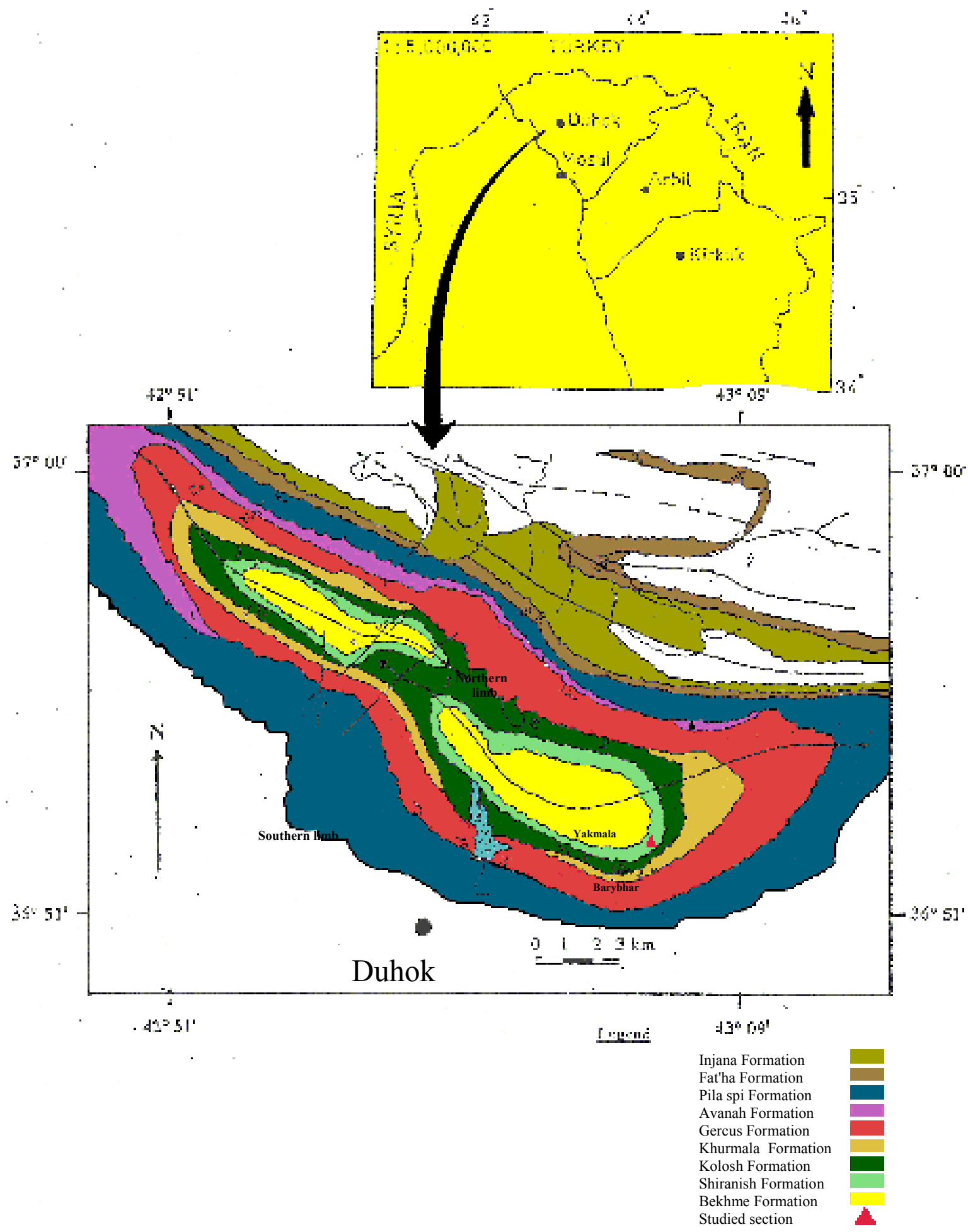

Fig. 1: Geological Map Explained the Studied Section, Modified from (F.A.O. 1994). 


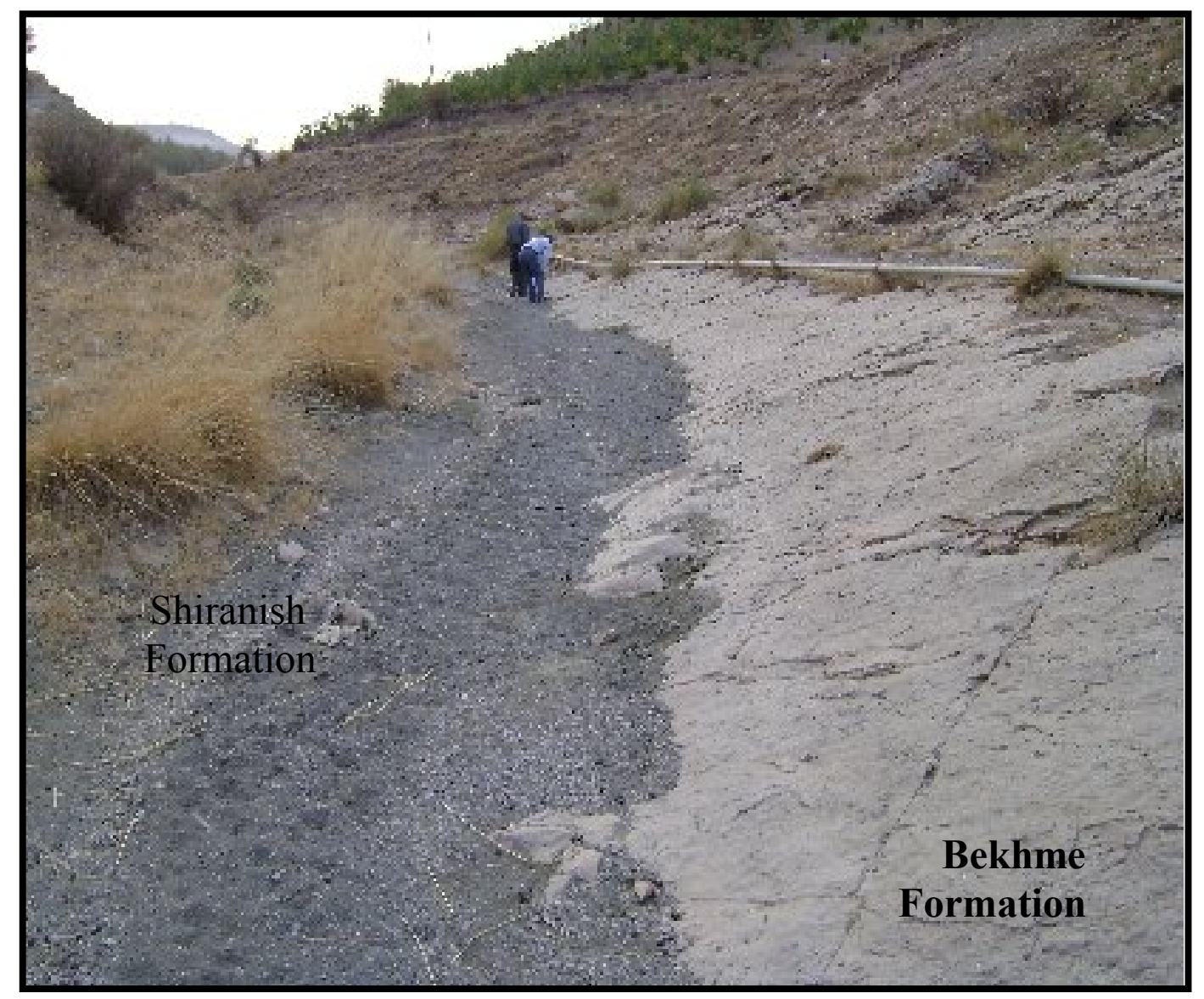

Fig.2: Field View of the Lower Boundary of the Shiranish Formation with Bekhme Formation.

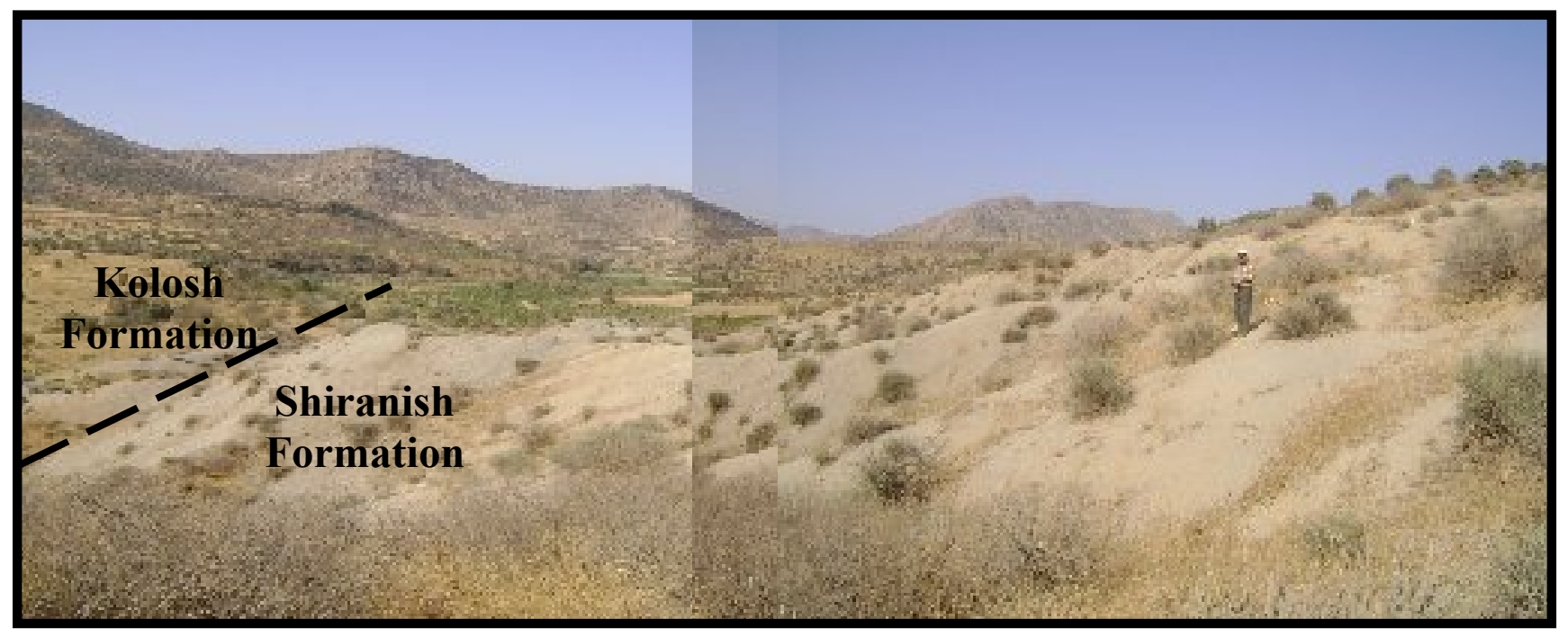

Fig. 3: Field View of the Upper Boundary of the Shiranish Formation with Kolosh Formation. 


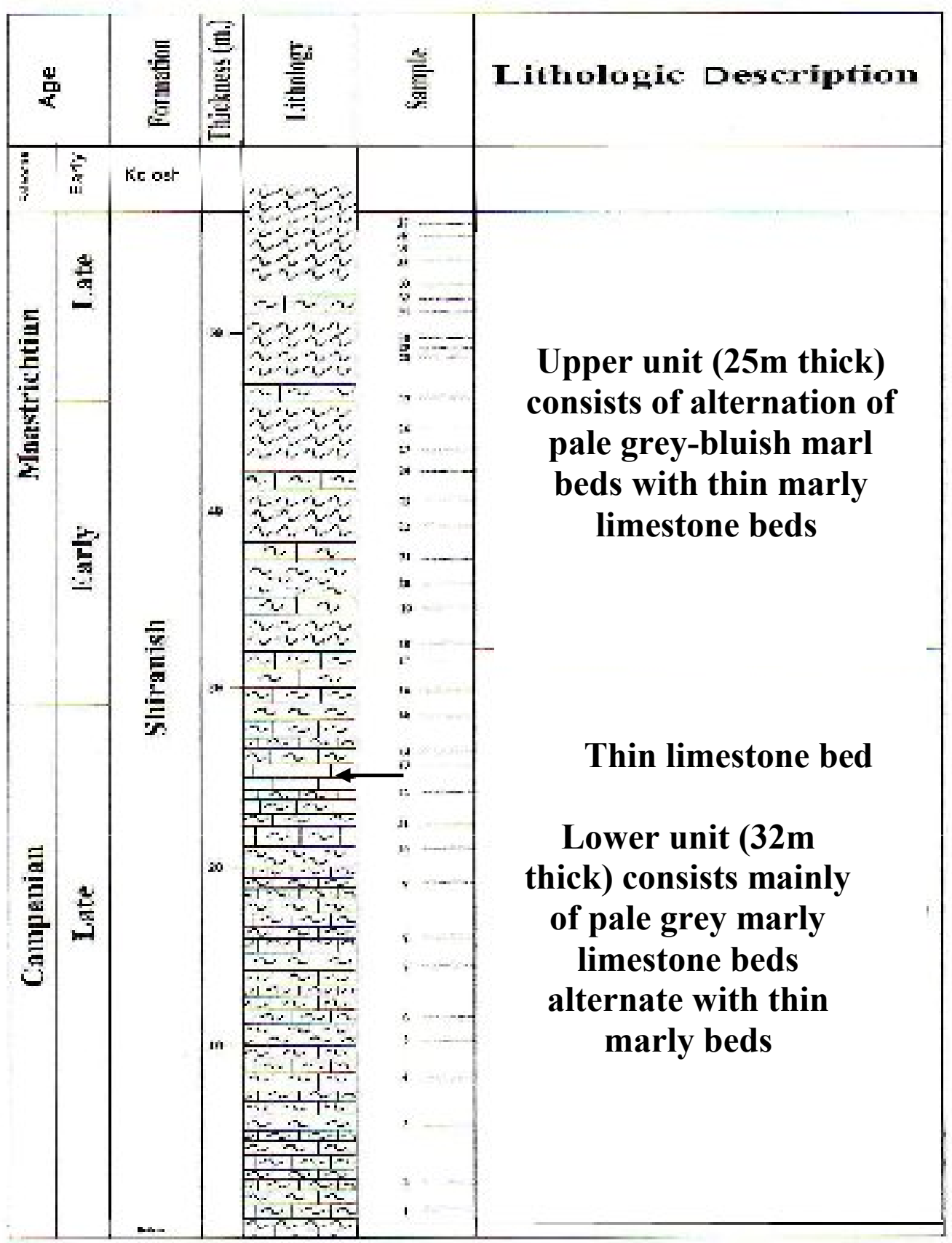

Fig. 4: Lithologic Description of Shiranish Formation in the Studied Section. 
The identified planktonic foraminiferal biozones were correlated with their equivalent standerd biozones in other regions of the world (Figs. 6 and 7). Furthermore, these biozones have been correlated locally with previous studies in Iraq. The studied section can be subdivided into eight biozones, these biozones were described below starting from older to younger.

\section{1- Globotruncana aegyptiaca Interval Zone(CF8)(Part):}

Definition: This zone was originally established by (Caron,1985). It represents the stratigraphic range of the index species Globotruncana aegyptiaca Nakkady which precede the appearance of Gansserina gansseri ( Bolli ).

Age: middle Late Campanian.

Boundaries: In this study the lower boundary is marked by unconformity and marked by the first appearance of index species Globotruncana aegyptiaca, whereas its upper boundary is indicated by first appearance of index species Gansserina gansseri ( Bolli ).

Thickness: $25.2 \mathrm{~m}$ represented by the samples ( $1-12$ ).

Correlation and Age Determination: The present zone is equivalent to the upper part of Globotruncana stuartiformis Zone of (Postuma, 1971), and to the Globotruncana aegyptiaca Zone of (Caron, 1985 and Sliter, 1989). It is equivalent to the Globotruncana aegyptiaca (CF8a) and Rugoglobigerina hexacamerata (CF8b) Zone of (Li et al., 1999) which are considered of Latest Campanian - Early Maastrichtian age. This zone is equivalent to Globotruncana aegyptiaca Zone of (Gradstein et al., 2004 ) which supports the same age of this zone.

Locally, in Iraq, this zone is equivalent to the upper part of Globotruncana arca - tricarinata - subcircumnodifer Subzone of (Kassab, 1979), and to the upper part of Rugotruncana subcircumnodi fer Subzone of (Abawi et al., 1982) and (Abdel Kireem, 1983). The present zone is correlatable with the Globotruncana aegyptiaca Zone of (AL-Juboury, 2002 and AL-Omari et al., 1994), and (AL-Mutwali and AL-Juboury, 2005) and (Bamerni, 2010), and equivalent to the same zone of (AL-Mutwali et al., 2008) and (AL-Haidary, 2009) which is considered by them of middle Late Campanian age.

\section{2- Gansserina gansseri Interval Zone(CF7) :}

Definition: This zone was introduced by Bronnimann (1952).It represents the stratigraphic range of the index species Gansserina gansseri ( Bolli ) which precede the appearance of Contusotruncana contusa ( Cushman ). 
Majid M. Al-Mutwali and Mazin A. AL-Doori

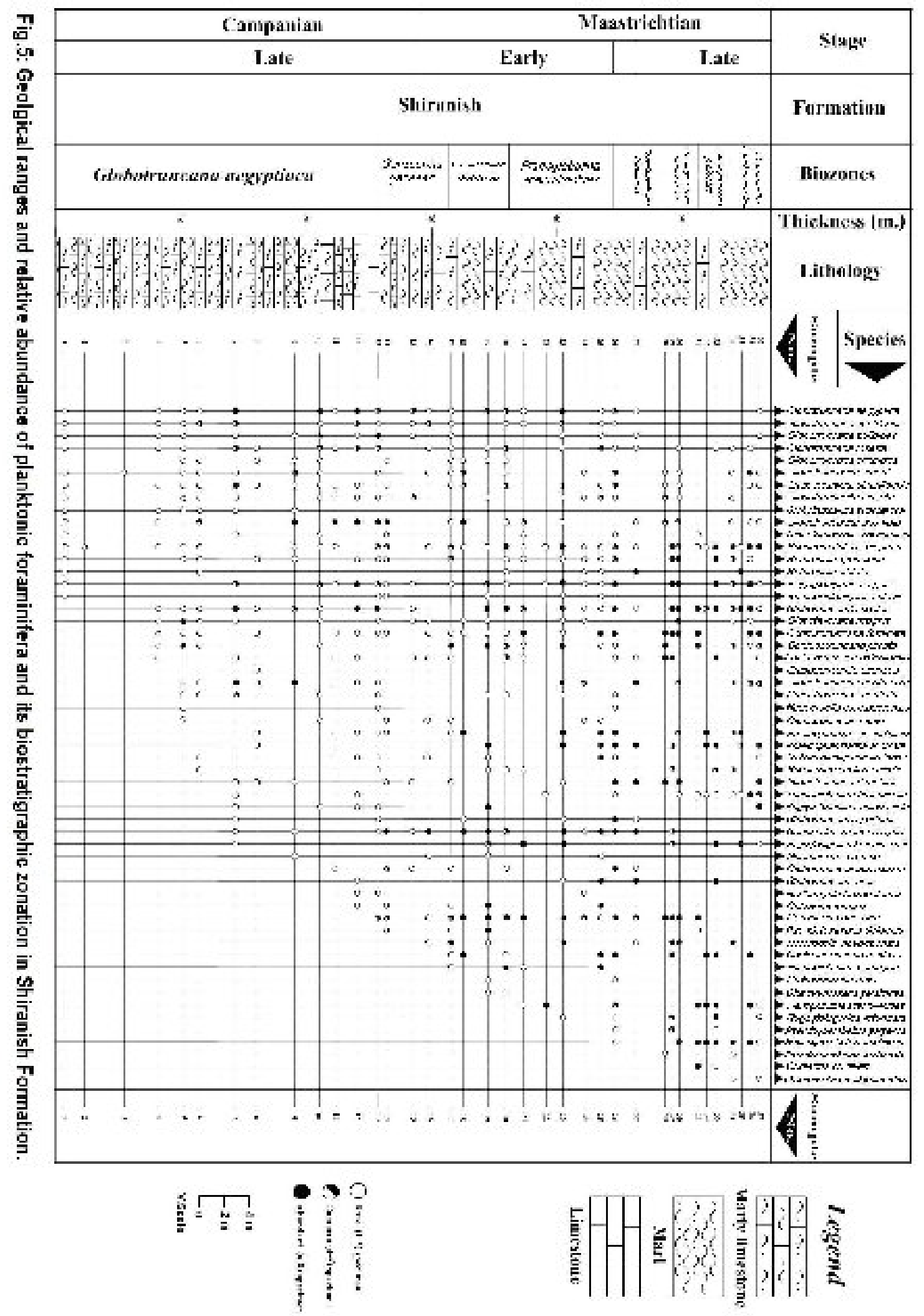


Planktonic Foraminiferal Biostratigraphy of Shiranish.

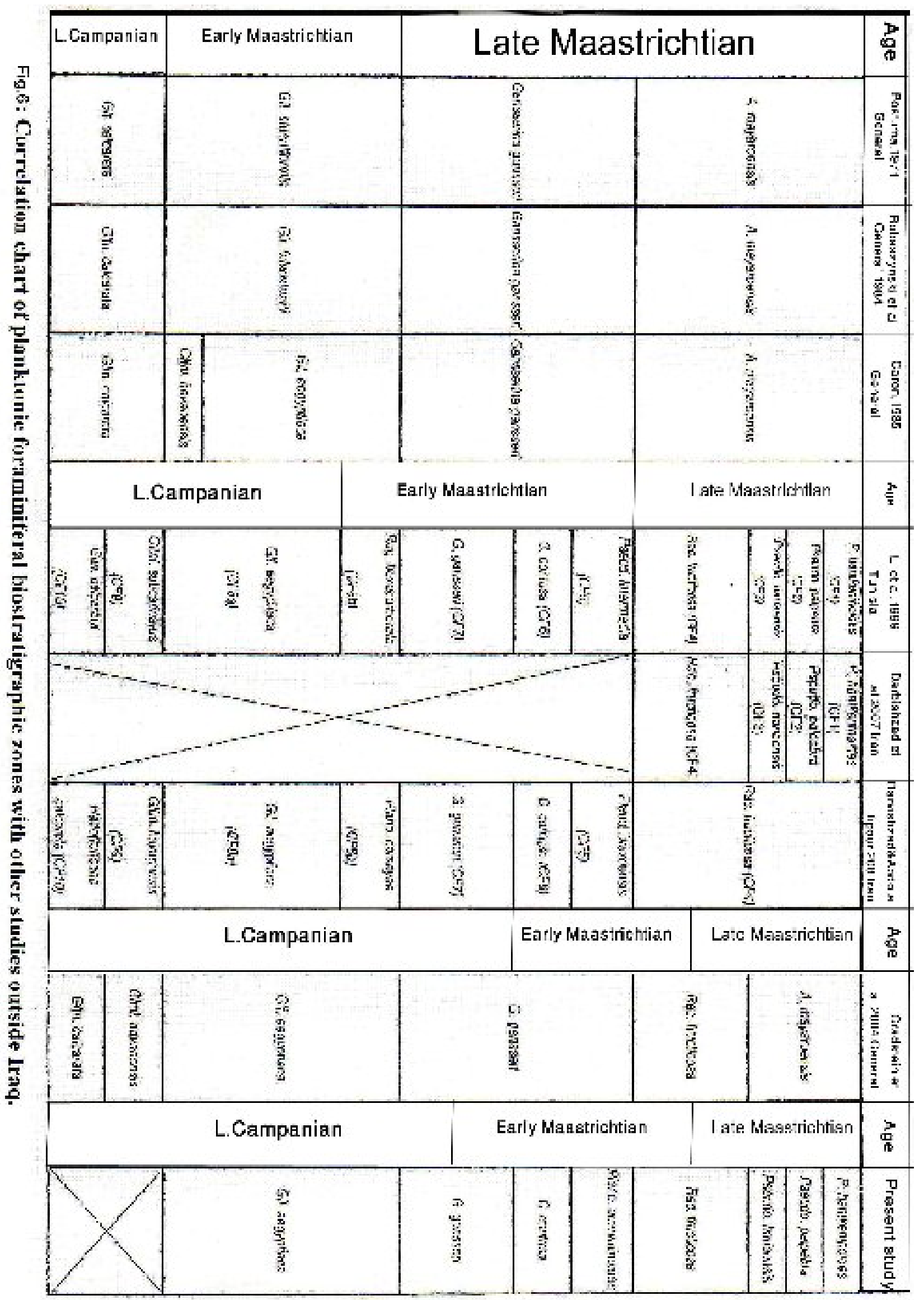


Majid M. Al-Mutwali and Mazin A. AL-Doori

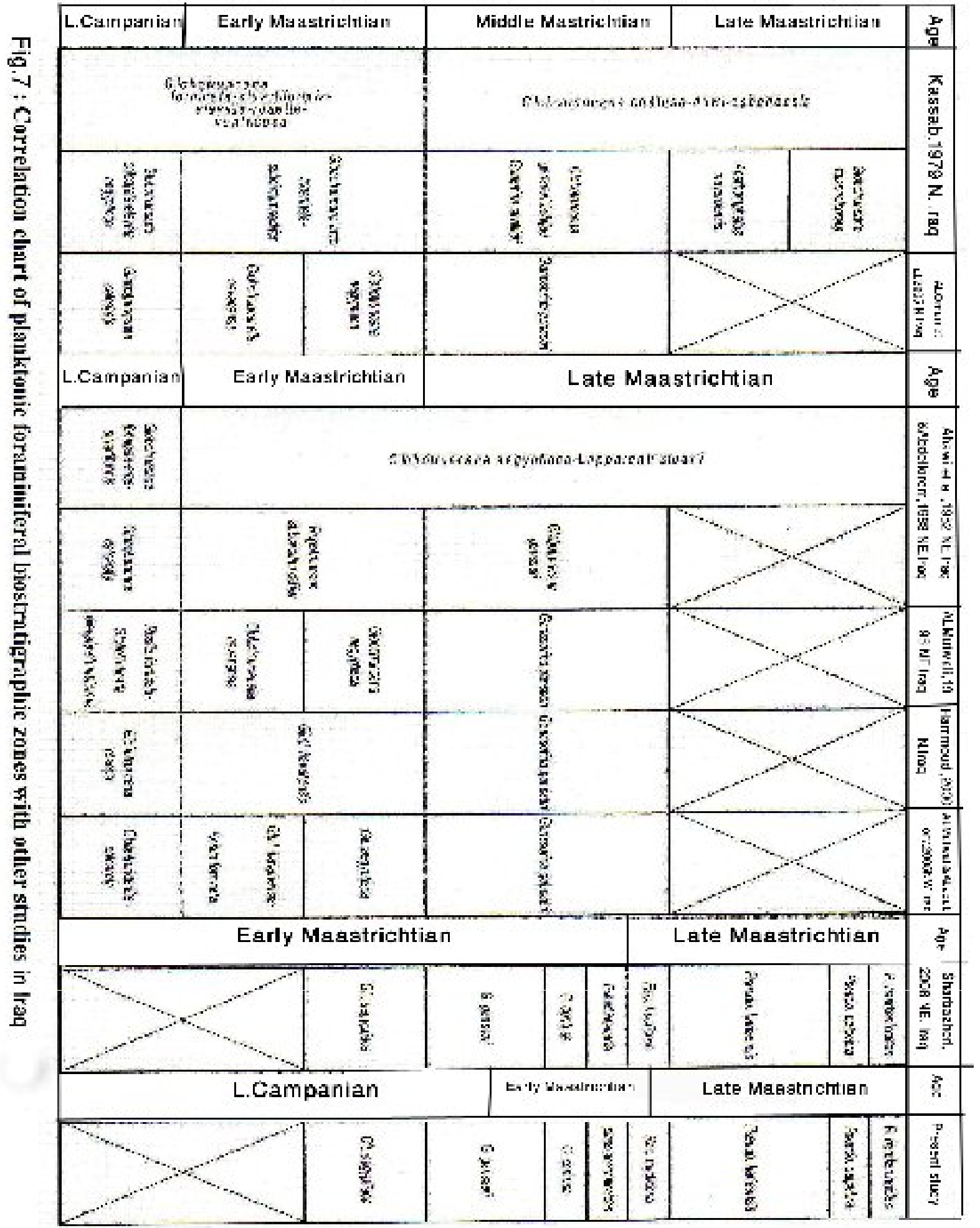


Age: latest Campanian - earliest Maastrichtian.

Boundaries: The lower boundary of this zone marked by the first appearance of Gansserina gansseri ( Bolli ), whereas its upper boundary is indicated by the first appearance of Contusotruncana contuse. ( Cushman ).

Thickness: $6 \mathrm{~m}$ represented by the samples ( $13-16$ ).

Correlation and Age Determination: The present zone is equivalent to the lower part of Gansserina gansseri Zone of (Postuma, 1971),(Robaszynski et al.,1984) (Caron, 1985), (Sliter, 1989) (Mogaddam, 2002). The present zone is equivalent to the Gansserina gansseri Zone ( CF7 ) of ( Li et al., 1999 ),(Gradestein et al., 2004) which they considered it of Late Campanian - Early Maastrichtian age.

Locally in Iraq, this zone is equivalent to Globotruncana gansseri - bahijae, Gublerina cuvillieri Subzone of (Kassab, 1973 and 1979), and to the lower part to Globotruncana gansseri Subzone of (Abawi et al., 1982). The present zone is equivalent to the lower part of Gansserina gansseri Zone of (Hammoudi, 2000), (AL-Joubory, 2002). this zone equivalent to Gansserina gansseri Zone of (AL-Haidary, 2009) which is considered it of Latest Campanian age.

\section{3- Contusotruncana contusa Interval Zone (CF6):}

Definition: This zone was originally proposd by Dalbeiez (1955), it represents the stratigraphic range of the index species Contusotruncana contusa (Cushman) from its first appearance at the base to the last appearance of Globotruncana linneiana ( d'Orbigny ) at the top.

Age: Early Maastrichtian.

Boundaries: The lower boundary of this zone is marked by the first appearance of Contusotruncana contusa ( Cushman ), where as its upper boundary is indicated by the last appearance of Globotruncana linneiana ( d'Orbigny ).

Thickness: $4.6 \mathrm{~m}$ represented by the sample ( $17-20)$.

Correlation and Age Determination: This zone is correlatable with Contusotruncana contusa (CF6 ) Zone of ( Li et al., 1999) and (Darvishzab and Abdolalipour, 2008) of Early Maastrichtian age, it is equivalent to the Lower part of Contusotruncana contusa Zone of (Dimitrova and Valcher, 2007) and Contusotruncana contusa Zone of (Rostami et al., 2009) which consedried it of Early Maastrichtian age. In Iraq this zone is corretable with Contusotruncana 
contusa Zone of (Sharbazheri, 2008 and 2010) and (Ismael, et al.,2011) which is assigned by them of Early Maastrichtian age.

\section{4- Planoglobulina acervulinoides Partial range Zone (CF5):}

Definition: This zone recorded by Arenillas et al.,2006, which represent the partial range zone of the index species Planoglobulina acervulinoides (Egger) between last appearance of Globotruncana linneiana ( d'Orbigny ) and first appearance of Racemiguembelina fructicosa (Egger).

Age : late Early Maastrichtian.

Boundaries: The lower boundary of this zone is marked by the last appearance of Globotruncana linneiana (d'Orbigny), while the upper boundary is indicated by the first appearance of Racemiguembelina fructicosa (Egger).

Thickness: $8.8 \mathrm{~m}$ represented by the samples $(21-25)$.

Correlation and Age Determination: The present zone is equivalent to the Pseudotextularia intermedia Zone (CF5) of (Li et al, 1999), to the Planoglobulina brazoensis Zone of (Darvishzab and Abdolalipour, 2008), (Rostami et al., 2009) which they considered it to be of Latest Early Maastrichtian age, and to the Planglobulina acervulinoides Zone which descrided from Early Maastrichtion deposits by (Arenillas et al., 2006). In Iraq this zone is correlated to the Pseudotextularia intermdia Zone of (Sharbazheri, 2008) which is assigned to the latest Early Maastrichtian age.

\section{5- Racemiguembelina fructicosa Interval Zone (CF4):}

Definition: This zone was introduced by Li and Keller(1998 a and b). It represents the stratigraphic range of the index species Racemiguembelina fruticosea (Egger) which precede the appearance of Pseudoguembelina hariaensis Nederbragt.

Age: early Late Maastrichtian.

Boundaries: The lower boundary of this zone is marked by the first appearance of Racemiguembelina fructicosa (Egger), whereas its upper boundary is marked by the first appearance of Pseudoguembelina hariaensis Nederbragt.

Thickness: $3.2 \mathrm{~m}$ that represented by the samples $(26-27)$. 
Correlation and Age Determination: This zone is apparently equivalent with Racemiguembelina fructicosa Zone which described by (Li et al., 1999), (Darvishzad and Abdolulipour, 2008), (Rostami et al., 2009) of Early late Maastrichtian age, and correlated to the upper part of Globotruncana contusa Racemiguembelina fructicosa Zone of (Premoli Silva et al., 1998), and (Arenillas et al., 2006).

Locally in Iraq this zone is correlated with Racemiguembelina fructicosa Zone of ( Sharbazheri, 2008 ) which considered it of early Late Maastrichtion age.

\section{6- Pseudoguembelina hariaensis Interval Zone (CF3):}

Definition: This zone was originally defind by Li and Killer (1998a).the Interval zone which represnted by the stratigraphic range of the index species Pseudoguembelina hariaensis Nederbrogt between its first appearance and the last appearance of Gansserina gansseri ( Bolli ).

Age: middle Late Maastrichtian.

Boundaries: The lower boundary of this zone is marked by the first appearance of Pseudoguembelina hariaensis Nederbragt, whereas its upper boundary is marked by the last appearance of Gansserina gansseri (Bolli).

Thickness: $3.6 \mathrm{~m}$ represented by the samples ( $28-31$ ).

Correlation and Age Determination: The present zone is equivalent to the Pseudoguembelina hariaensis Zone which described by(Li et al., 1999), (Arenillas, et al., 2006) and (Darvishzad et al., 2007), they considered it to be of middle Late Maastrichtian age.

Locally in Iraq the zone is correlated with Pseudoguembelina hariaensis Zone of (Shanbazheri, 2008) which assigned it to the middle Late Maastrichtian age.

\section{7- Pseudoguembelina palpebra Partial range Zone (CF2):}

Definition: This zone was defined by Li and Keller(1998 a and b), it represent the partial range of Pseudoguembelina palpebra Bronnimann and Brown between the last appearance of Gansserina gansseri (Bolli) and the first appearance of Plummerita hantkeninoides ( Bronnimann ).

Age: Late Maastrichtian.

Boundaries: The lower boundary of this zone is marked by the last appearance of Gansserina gansseri (Bolli), whereas its upper boundary is marked by the first appearance of Plummerita hantkeninoides (Bronnimann). 
Thickness: $1.8 \mathrm{~m}$ that represented by the samples ( $32-33$ ).

Correlation and Age Determination: The present zone is equivalent to the Pseudoguembelina palpebra Zone of (Li et al., 1999), (Darvishzad et al., 2007) which they considered it of Late Maastrichtian age. Locally in Iraq, this Zone is correlated with Pseudoguembelina palpebra Zone of (Sharbazheri, 2008) which is assigned to the Latest Maastrichtian.

\section{8- Plummerita hantkeninoides Total range Zone (CF1)(Part):}

Definition: This zone was introduced by( Pardo, et al., 1996), which defined by the total range of the nominate taxon.

Age: Latest Maastrichtian.

Boundaries: The lower boundary of this zone is marked by the first appearance of Plummerita hantkeninoides ( Bronnimann ), while its upper boundary is marked by its last appearance.

Thickness: $3.8 \mathrm{~m}$ represented by the samples ( $34-37$ ).

Correlation and Age Determination: Plummerita hantkenincides is easily identified within the uppermost part of Late Maastrichtian, the range of this excellent marker species spans the youngest $300 \mathrm{kyr}$ of the Maastrichtian below the Cretaceous / paleogene boundary ( keller et al., 2002). The present zone is equivalent to the Plummerita hantkeninoides Zone ( CF1) which described by (Li et al., 1999), (Darvishzad et al., 2007), they considered it of Latest Maastrichtian age, this zone is also correlated with the upper part of Abathomphalus mayaroensis Zone of (Robaszynski et al., 1984) (Caron, 1985), ( Premoli Silva et al.,1998 ) ( Chacon et al., 2005 ) of Late Maastrichtian age.

In Iraq this Zone is equivalent to the upper part of Kassabiana falsocalcarata Zone of ( Kassab et al., 1986 ) of Late Maastrichtian age, it is also correlated with Plummerita hantkeninodes Zone which is described by ( Sharbazheri., 2008 ) of Latest Maastrichtian age. 


\section{CONCLUSION}

Planktonic foraminiferal investigation of the Upper Cretaceous Shiranish Formation in Dohuk area northern Iraq yielded 55 species that belong to 16 genera, According to their stratigraphic range, the formation divided into eight zones. The distribusion of faunal sequence and the correlation between these zones and other zonal schems in and outside Iraq reveals a middle Late Companian age for the first zone and Late Campanian - Early Maastrichtian for the second zone, whereas other six biozones extended from Early - Late Maastrichtian.

\section{REFERENCES}

Abawi, T. S., Abdel - Kireem, M. R. and Yousef, J. M., 1982. Planktonic Foraminiferal Stratigraphy of Shiranish Formation, Sulaimaniah-Dokan Region, Northeastern Iraq. Revista. Esp.d, Micropaleontologia, Vol. .14, No.1, p. 153 - 164.

Abdel - Kireem, M. R., 1983. A study of the Palaeoecology and Bathymetry of the Foraminiferal Assemblages of the Shiranish Formation (Upper Cretaceous), Northeastern Iraq. Palaeogeo., Palaeoclim., Palaeoeco., Vol. 43, pp. 169 - 180.

AL-Haidary, L. Y., 2009. Stratigraphy and Depositional Environment of Bekhme Formation and the Nature of its Contact with Shiranish Formation in Dohuk Area, North of Iraq. Unpublished M.Sc. Thesis, University of Mosul, Iraq. 131p. (in Arabic with English abstract).

AL-Juboury, F. N. , 2002. Foraminiferal Biostratigraphy and Paleoecology of Shiranish Formation in Sinjar Area, North west Iraq, Unpublished M. Sc.

Thesis. University of Mosul, Iraq. 79 p. (in Arabic with English abstract).

Al-Mutwali, M. M. ,Al-Juboury, F. N., 2005. Petrography and Biostratigrphy of Shiranish Fomation (Late Campanian-Late Maastrichtian)in Sinjar Area northwest Iraq. Raf. Jour.Sci,Vol. 16, No.1, pp. 152 - 176.

Al-Mutwali, M. M., Al-Banna, N. Y. and Al-Ghrear, J. S., 2008. Microfacies and Sequences Stratigraphy of the late Campanian Bekhme Formation in Dohuk Area, North Iraq. GeoArabia, Vol. 13, No. 1, pp. 39 - 54.

Al-Omari, F. S., Kassab, I.I. and Dawood, S., 1994. Planktonic foraminifera and biostratigraphy of Shiranish and Aaliji formations in well Mushorah (No. 1) Northwestern Iraq. Jour. Geo. Iraqi, Vol. 27, No. 1, pp. 60 - 74. 
Al-Omari, F. S., Sabah, N., Omar, A., 2005. Biostratigraphy of Planktonic Foraminifera within Shiranish Formation (LateCampanian-Middle Maastrichtian) in Butmah well No.15 Northwest Iraq. Iraqi, Nat. Jou.of Earth Science, Vol. 5, No. 1, pp. 32 - 43.

AL-Wazan, A. M., 2007. Planktonic Foraminiferal Biostratigraphy of kolosh Formation (Paleocene) in Dohuk Area North Iraq .unpublished M.Sc. Thesis University of Mosul, Iraq. 68 p. (in Arabic with English Abstract).

Arenillas, I., Arz J. A., Grajales, JM-Ni Shimura, Murillo, G-Muneton, Alrarez, W., Camargo, A-Zonoguera, Molina, E., Rosales, C-Doniguez, 2006. Chicxulub Iimpact Events in Cretaceous/ Paleogene boundary in Age: New Microplaeotological Evidence, Earth and Planetary Science Letters, Vol.. 249, pp. $241-254$.

Bamerni, A. A., 2010. Biostratigraphy of the Shiranish Formation in the Subsurface Section of Khanke Well No. 1 Dohuk Area North Iraq. Unpublished M.Sc. Thesis University of Mosul, Iraq (in Arabic with English Abstract).

Bellen, R.C.Van, Dunnington, H.V., Wetzel, R. and Morton, D. M., 1959, Lexique Stratigraphique International. Asie, Fasc., 10a, Iraq, 333 p.

Caron, M., 1985. Cretaceous Planktic Foraminifera. In: Bolli, H. M., J. R. Saunders and K. Perch-Nielsen (eds.) Planktonic Stratigraphy, Cambridge Univ. Press, pp. 17 - 86, Figs. 37.

Chacon, B. and Chivelet, J. M., 2004. Major Paleoenvironmental Changes in the Campanian to Paleocene Sequence of Caravaca (subbetic zone, Spain), Journal Ibrian Geo., Vol.. 31, No. 2, pp. 299 - 310.

Darvishzad, B. and Abdolalipour S., 2008. Campanian and Masstricthian Biostratigraphy and Paleoenvironment in Jorband Section, North of Iran. Jour. of Sciences, Iran, Vol. 1, No. 1, pp. 1 - 17.

Darvishzad, B., Nejad, E. Gh., Ghourchaei, S. and Keller, G., 2007. Planktonic Foraminiferal Biostratigraphy and Faunal Turnover Across the CretaceousTertiary Boundary in Southwestern Iran. Jour of Sciences, Iran, Vol. 18, No. 2, pp. 139 - 149.

Dimitrova, E. and Valchev, B., 2007. Attempt for Upper Cretaceous Planktonic Foraminiferal Zonation of the Srednogorie and Eastern Balkan Zones (Bulgaria), Geologica Balcanica, Vol. 36, No. 1 - 2, pp. 55 - 63.

Gradstein, F. M. Ogg J. G. Smith A. G. Bleeker W. and Lourens, L. J., 2004.

A New Geologic Time Scale with Special Reference of Precambrian and Neogene Episodes, Vol. 27, No. 2, pp. 83 - 100.

Hammoudi, R. A., 2000. Planktonic Foraminiferal Biostratigraphy of the Shiranish Formation (Upper Cretacous) in Jambur Well No. 13 Northern Iraq. Raf. Jour. Sci., Vol.. 11, No. 4, pp. 50 - 58. 
Ismael, K., M. ,Khanaqa, P. A. and Karime, K. H., 2011. Biostratigraphy of Bluish Marl Succession (Maastrichtian) in Sulainanyia Area. Kurdistan region, NE-Iraq. Iraqi Nat. Jou . of Earth Science, Vol. 11, No. 2, pp. 81 - 99.

Jassim and Buday In Jassim, S. Z. and Goff, J. C, 2006. Geology of Iraq. Published by Dolin, Prague and Moravian Mus. Brno, 341p.

Kassab, I. I., 1973. Planktonic Foraminiferida of the Shiranish Formation Type Locality, Northern Iraq. Jour. Geol. Soc. Iraq, Vol. 1, pp. 100 - 109.

Kassab, I. I., 1979.The Genus Globotruncana Cushman from the Upper Cretaceous of Northern Iraq. Jour. Geol. Soc. Iraq Vol. 12, No. 1, pp. 27 - 127.

Kassab, I. I. M., AL-Omari, F. S. and AL-Safawee, N. M., 1986. The Cretaceous -

Tertiary Boundary in Iraq (Represented by the Subsurface Section of Sasan Well

No. 1, NW Iraq). Jour. Geol. Iraq, Vol. 19, No. 2, pp. 73 - 86.

Keller, G., Adatte, T., Stinnesbeck, W., Luciani, V., Yaakoub, N. K. and Turki, D.

Z. 2002. Paleoecology of the Cretaceous-Tertiary Mass Extinction in Planktonic Foraminifera. Palaeogeo. Palaeoclim. Palaeoeco., Vol. 178, pp. $257-297$.

Li, L., Keller, G. and Stinnesbeck, W., 1999 The Late Campanian and Maastrichtian in Northwestern Tunisia: Palaeoenvironment Inferences from Lithology, Macrofauna and Benthic Foraminifera. Cretaceous Research, Vol. 20 issue 2, pp. $231-252$.

Mogaddam, H.V., 2002: Biostratigraphic Study of the Ilam and Gurpi Formations Based on Planktonic Foraminifera in SE of Shiraz, Iran, Jour. National Centre for Research . Iran, Vol. 13, No. 4, pp. 339 - 356.

Pardo, A., Ortiz, N. and Keller, G., 1996. Latest Maastrichtian Foraminiferal Turnover and its Environmental Iimplications at Agost, Spain. In: Macleod, N. and Keller, G. (eds.), Cretaceous -Tertiary Mass Extinction: Biotic and Environmental changes. Norton, w. and Co., New York:1 pp. 39 - 172.

Postuma, J. A., 1971. Manual of Planktonic Foraminifera. Elsevier Pub Co., Amsterdam. 420 p.

Premoli Silva, I, Spezzaferri S and D'Angelantonio A, 1998. Cretaceous Foraminiferal Biostratigraphy of Hole 976E and Peleogene Planktonic Foraminiferal Biostratigraphy of Hole 966E, Eastern Mediterranean. Proceedings of the Ocean Drilling Program, Scientific Results Vol. 160, pp. $377-394$.

Robaszynski, F, Caron, M, Gonzalez, D. J. M and Wonders, A. A. H. 1984. Atlas of Late Cretaceous Globotruncanids Revue Micropal, Revue Micropal., Vol. 26, No. (3 - 4), pp. 145 - 305.

Rostami, M. A., Balmaki, B., Ardestani, M. Sh., Kohansal, E., 2009. Biostratigraphy and Assigning the Paleosalinity by Using Echinocorys and Planktonic Foraminifera at Upper Maastrichtian in Jorband Section, Central Albroz, Iran, Nature Precedings doi: 10.1038/npre. 3699. Vol. 1, pp. 1 - 7. 
Sharbazheri, Kh, M. I., 2008. Biostratigraphy and Paleoecology of Cretaceous/ Tertiary Boundary in the Sulaimania Region, NE Iraq. Unpublished PhD Thesis, University of Sulaimania Iraq $200 \mathrm{p}$.

Sharbazheri, Kh, M. I., 2010. Planktonic Foraminiferal Biostratigraphy of the Reddish to Pale Brown Transitional Succession (Upper Cretaceous) in Smaquli Area, Northeast Iraq.(Kurdistan Region ).Iraqi Bulletin of Geology and Mining Vol..6, No. 1, pp. 1 - 20.

Sliter, W. V., 1989. Biostratigraphic Zonation for Cretaceous Planktonic Foraminifera Examined in thin Section. Jour. Foram. Research, Vol. 19, No. 1, pp. 1 - 19. 


\section{PLATE 1}

Fig. 1a: Globotruncanita angulata (Tilev). Umbilical side. Sample No. 6.

Fig. 1b: Globotruncanita angulata (Tilev). Spiral side. Sample No. 6.

Fig. 2a: Globotruncana rosetta (Carsey). Spiral side. Sample No. 8.

Fig. 2b: Globotruncana rosetta (Carsey). Umbilical side. Sample No. 8.

Fig. 3a: Globotruncana aegyptiaca Nakkady. Spiral side. Sample No. 4.

Fig. 3b: Globotruncana aegyptiaca Nakkady. Umbilical side. Sample No. 4.

Fig. 4a: Globotruncana insignis Gandolfi. Spiral side. Sample No. 8.

Fig. 4b: Globotruncana insignis Gandolfi. Umbilical side. Sample No. 8.

\section{PLATE 2}

Fig. 1a.: Globotruncana duwi Nakkady. Spiral side. Sample No. 20.

Fig. 1b.: Globotruncana duwi Nakkady. Umbilical side. Sample No. 20.

Fig. 2.: Pseudotextularis elegans (Rzehak). Side view. Sample No. 27.

Fig. 3.: Pseudotextularis deformis (Kikoine). Edge view. Sample No. 20.

Fig. 4a.: Gansserina gansseri (Bolli). Edge view. Sample No. 26.

Fig. 4b.: Gansserina gansseri (Bolli). Umbilical side. Sample No. 26.

Fig. 5: Gansserina wiedenmayei (Gandolfi). Side view. Sample No. 26.

Fig. 6: Globotruncanella havanensis (Voorwijk). Spiral side. Sample No. 27. 
Majid M. Al-Mutwali and Mazin A. AL-Doori

\section{Plate 1}

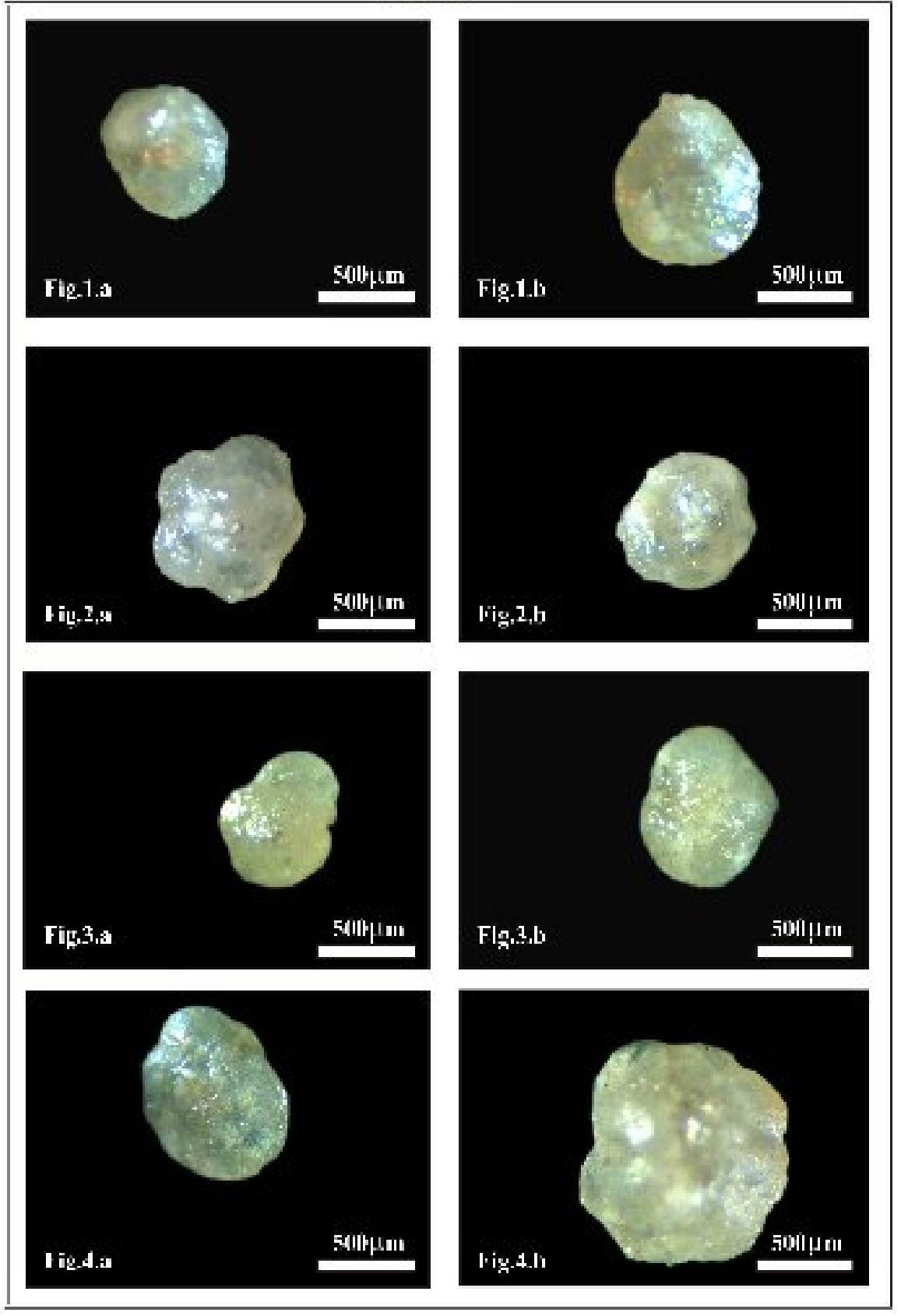




\section{Plate2}
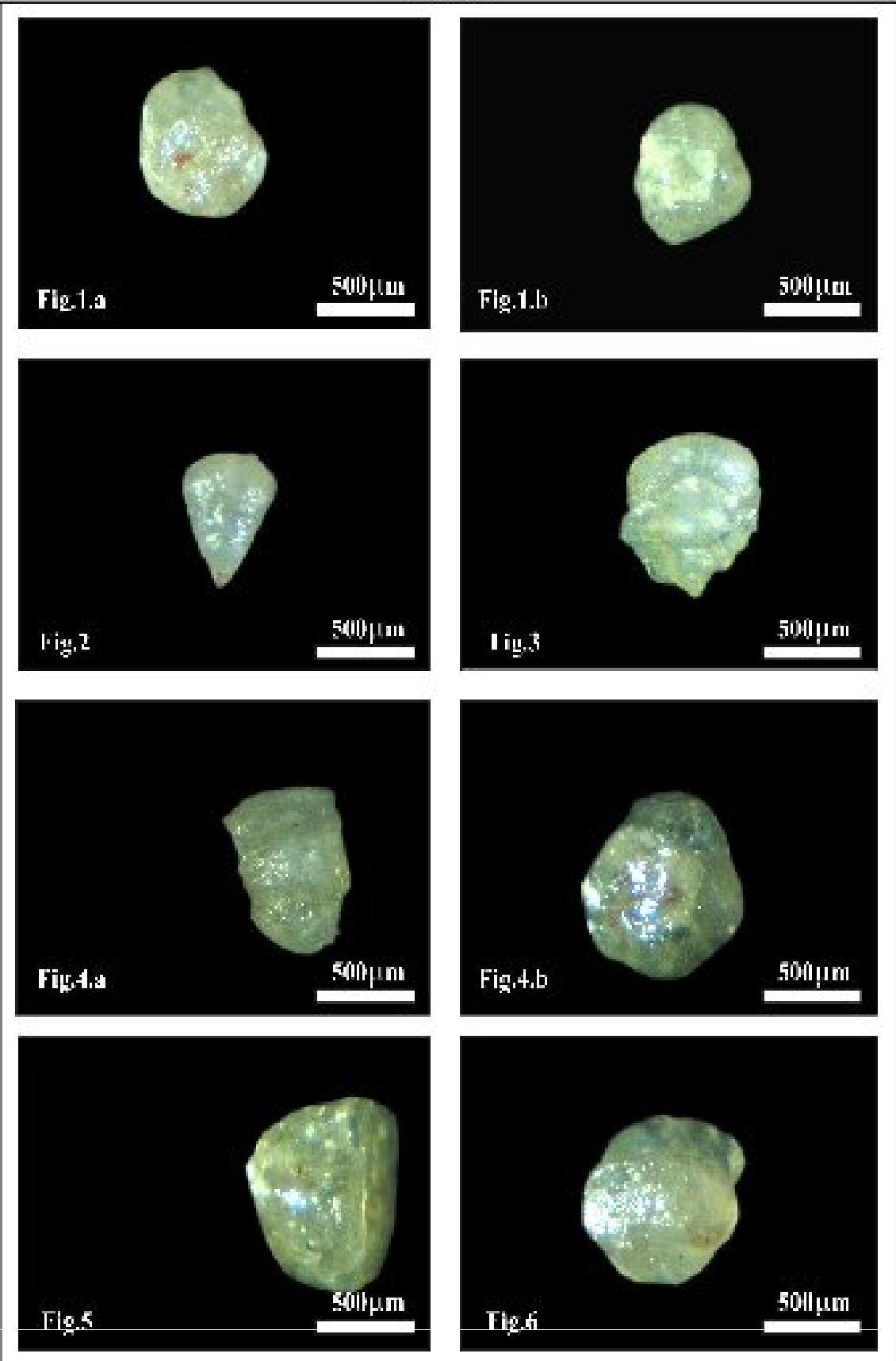


\section{PLATE 3}

Fig. 1a.: Globotruncana falsostuarti Sigal. Spiral side. Sample No. 12.

Fig. 1b.: Globotruncana falsostuarti Sigal. Umbilical side. Sample No. 12.

Fig. 2.: Globotruncanella petaloidea (Gandolfi). Spiral side. Sample No. 20.

Fig. 3a.: Contusotruncana contusa (Cushman). Spiral side. Sample No. 35.

Fig. 3b.: Contusotruncana contusa (Cushman). Side view. Sample No. 35.

Fig. 4.: Rugoglobigerina macrocephala Bronnimann. Umbilical side. Sample No. 12.

Fig. 5.: Rugoglobigerina rugosa (Plummer). Umbilical side. Sample No. 8.

Fig. 6: Rugoglobigerina hexacamerata Bronnimann. Umbilical side.Sample No. 22.

\section{PLATE 4}

Fig. 1: Planoglobulina carseyae (Plummer). Side view. Sample No. 24.

Fig. 2.: Planoglobulina brazoensis Martin. Side view. Sample No. 31.

Fig. 3.: Planoglobulina acervulinoides (Egger). Side view. Sample No. 31.

Fig. 4.: Pseudoguembelina palpebra Bronnimann and Brown. Side view, Sample. No. 30.

Fig. 5.: Racemiguembelina fructicosa (Egger). Side view. Sample No. 31.

Fig. 6.: Racemiguembelina powelli Smith and Pessagno. Side view.Sample No. 30.

Fig. 7.: Pseudoguembelina hariaensis Nederbragt. Side view. Sample No. 35.

Fig. 8.: Plummerita hantkeninoides (Bronnimann). Spiral side. Sample No. 35 


\section{Plate 3}
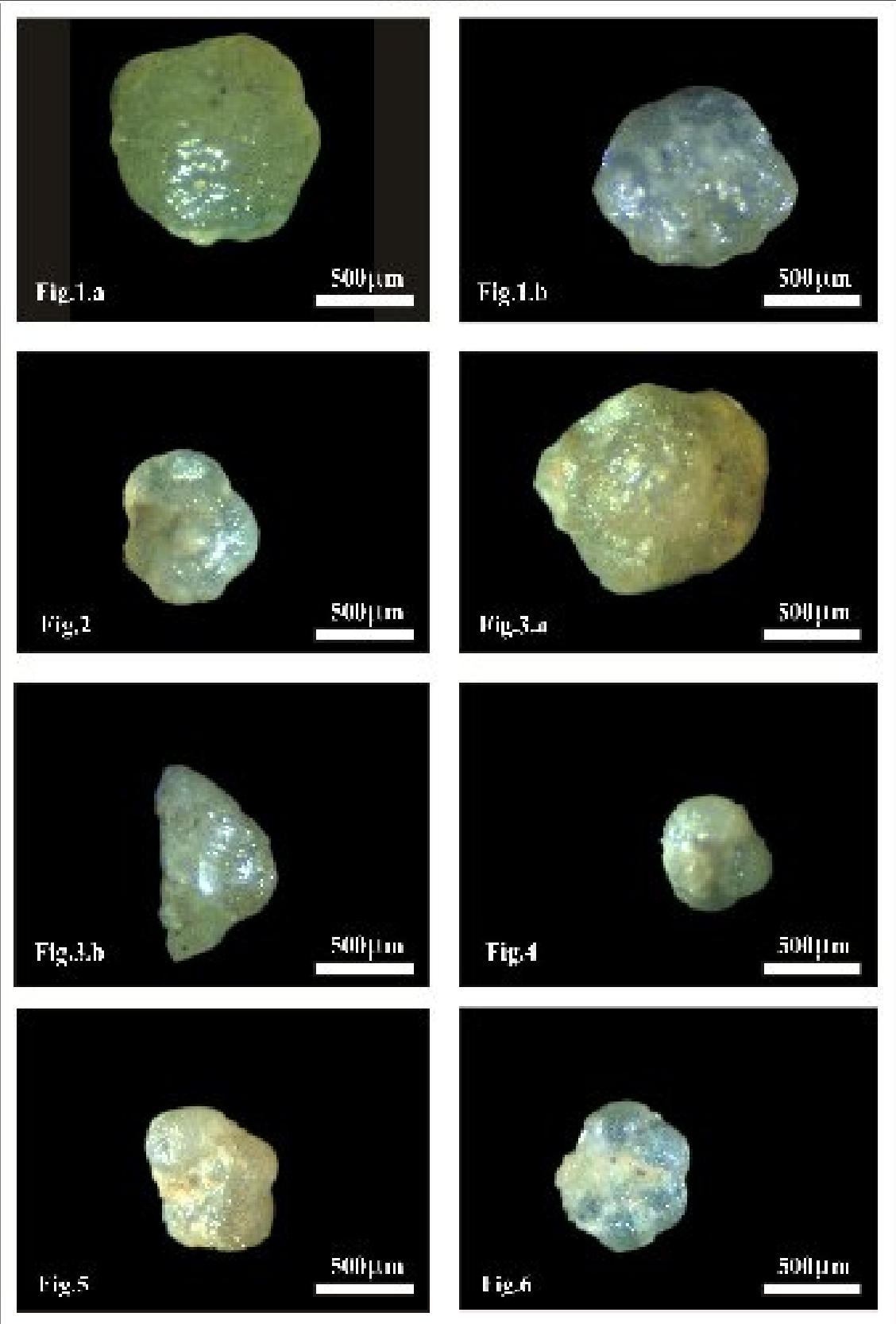
Majid M. Al-Mutwali and Mazin A. AL-Doori

Plate 4
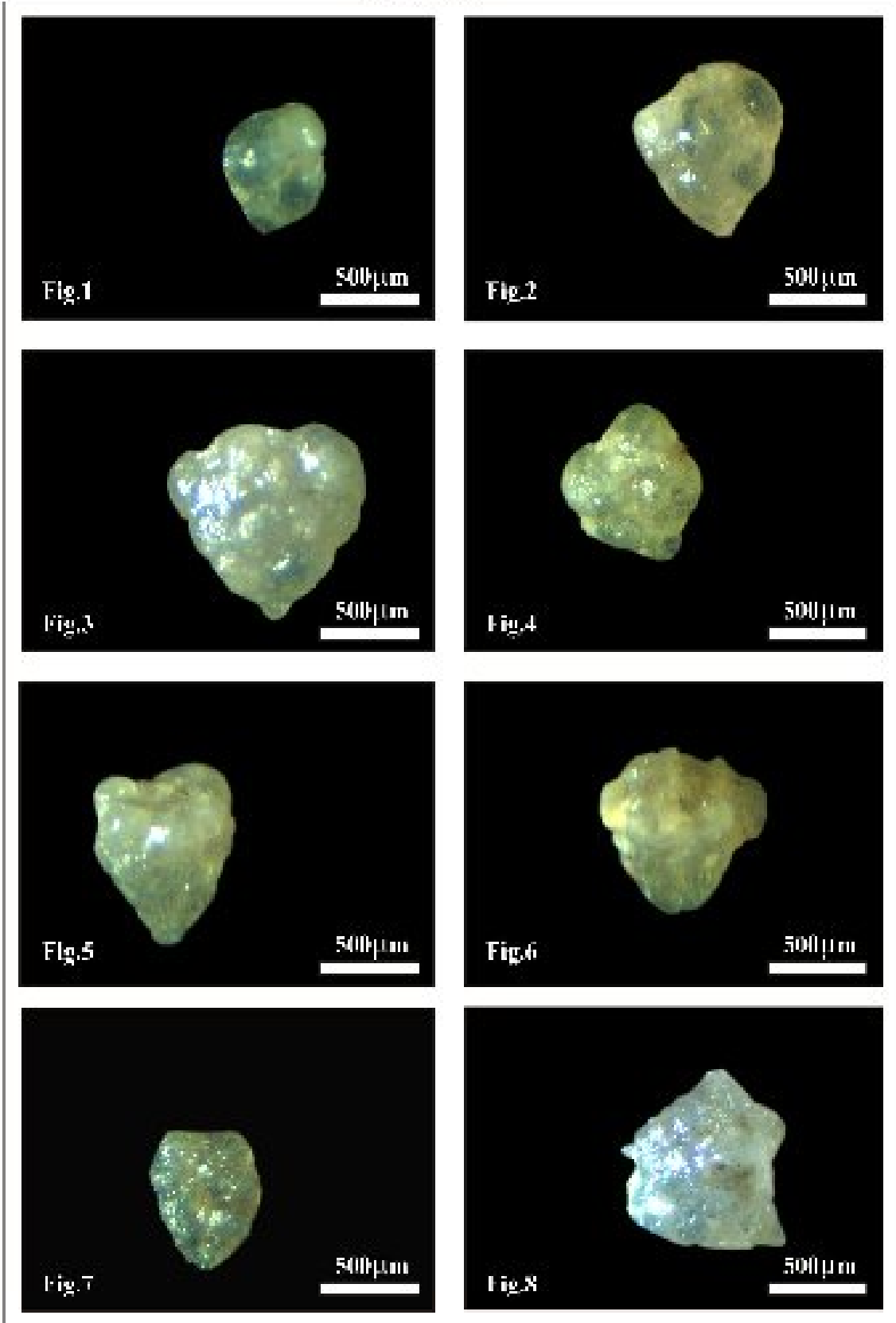